\title{
THE INFLUENCE OF ASSIGNMENT METHODS ON THE DEVELOPMENT ASPECTS OF RELIGIOUS AND MORAL VALUES OF EARLY CHILDHOOD DURING THE COVID-19 PANDEMIC
}

\author{
Erni Munastiwi \\ Universitas Islam Negeri Sunan Kalijaga \\ Caturtunggal, Sleman, Yogyakarta, Indonesia, 55281 \\ E-mail:erni.munastiwi@uin-suka.ac.id \\ Siti Marpuah \\ Universiti Tun Hussein Onn Malaysia \\ Parit Raja, Batu Pahat, Johor, Malaysia \\ E-mail:marpuah@uthm.edu.my
}

\begin{tabular}{c|c|c}
\hline Received: & Revised: & Approved: \\
$04 / 03 / 2021$ & $12 / 05 / 2021$ & $24 / 05 / 2021$ \\
\hline
\end{tabular}

DOI : https://doi.org/10.32332/akademika.v26i1.3143

\begin{abstract}
(c) (i) (2)
The Influence of Assignment Methods on the Development Aspects of Religious and

Moral Values of Early Childhood during the Covid-19 Pandemic Licensed Under a

Creative Commons Attribution-ShareAlike 4.0 International License
\end{abstract}

\begin{abstract}
The covid-19 pandemic period has not yet passed. Learning activities are carried out online or through distance learning. Distance learning requires teachers to assign tasks to children to keep learning from home every day. This research aims to see how assignment approaches affect the development of religious and moral values in early childhood in IT ADAR PAUD institutions during the Covid-19 pandemic. This study examines the significance test between the independent variables of the assignment system and the dependent variable of early childhood religious and moral values using quantitative correlation research of product-moment through the $t$-test. The significance value of 0.753 is greater than 0.05 , as shown by the t-test. As a result, it can be inferred that the assignment process has an effect on facets of religious and moral values formation in early childhood during the Covid-19 pandemic period. It is expected that educators in the pandemic period will continue to use the assignment method to ensure that facets of children's religious and moral beliefs evolve with time.
\end{abstract}

Keywords: Early Childhood, Assignment Methods, Religious and Moral Values

\section{A. Introduction}

Following the Covid-19 pandemic, PAUD (Early Childhood Education) educators are having trouble instilling religious and moral values in religious education for young children. As a result of the Covid-19 pandemic, recent legislation introducing online learning has emerged, demonstrating that PAUD educators cannot instill religious and moral values in early childhood. Educators are constrained by the implementation of indirect religious and moral values teaching. The result is that 
children find it difficult to understand religious and moral values directly through habituation and teaching carried out by teachers during the Covid-19 pandemic ${ }^{1}$.

Adult involvement in directing and stimulating PAUD age children is essential for the development of religious and moral values. This is intended to help children comprehend more of the content they are learned daily. These habits must be instilled in children at an early age for them to develop properly. It is important to conduct because the child's age is classified as a golden age that is ready to receive stimulation, support, and guidance directly from parents or teachers at school. This condition necessitates a suitable approach for improving and cultivating all facets of child development by PAUD science/discipline that is systematic, organized, and fascinating ${ }^{2}$.

The development of children's religious beliefs and morals is influenced by stimulating their growth and development through engaging and formal teaching methods ${ }^{3}$. According to research, educators, including parents and students, should provide a unique approach to instilling religious values and morals in early PAUD children in a fun way. The teacher can implement this approach by fostering a passion for God, demonstrating the value of positive morals and behavior, guiding children to live physically and spiritually healthy lifestyles, and educating them about diverse faiths and morality acts in an appealingly planned task ${ }^{4}$.

Educators carry out programs to improve children's religious and moral values consistently through habituation. This is what is referred to as early childhood education, which aims to stimulate children's golden years by increasingly shaping their values and morals. Rousseau exemplified it with a blacksmith who wanted to make a sharp sword that could be used properly. The smith's job was to constantly mold and sharpen his blade until it was razor-sharp when used ${ }^{5}$. If we look at it from an educational standpoint, this blacksmith behaves as an instructor for both teachers and parents who wish to enhance their children's growth and development by including them in repeated refraction exercises while they are between the ages of 0 and 6. Educators use this practice in programed and foundational PAUD teaching for early childhood6.

During the Covid-19 condition, the PAUD learning activities are also extended to early childhood. Due to the Covid-19 virus epidemic, educational institutions have had to shift from a traditional learning system to an online one. Learning activities are carried out at home using the online approach from early childhood education to higher education. This necessitates parental assistance for their children, especially for young children who do not understand how to use technology properly. According to

${ }^{1}$ Direktorat Pendidikan Agama Islam RI, “Bincang Mengenai Tantangan PAI Pada PAUD/TK Di Tengah Pandemi Covid-19," Pendis.Kemenag.Go.Id.

2 Anik Lestyaningrum, Perencanaan Pembelajaran Anak Usia Dini (Nganjuk: CV Adjie Media Nusantara, 2017), 4.

${ }^{3}$ Otib Satibi, Metode Pengembangan Moral Dan Nilai-Nialai Agama (Jakarta: Universitas Terbuka, 2013).

4 Cahyani and Suyadi, "Konsep Pendidikan Anak Usia Dini Menurut Ki Hadjar Dewantara," Golden Age: Jurnal Ilmiah Tumbuh Kembang Anak Usia Dini 3, no. 4 (2018): 219-230.

${ }^{5}$ Andini Widyastuti, Seabrek Kesalahan Guru PAUD (Yogyakarta: DIVA Press, 2016), 20.

${ }^{6}$ Nice Maylani Asril Ni Wayan Nariasih, Nyoman Wirya, "Penerapan Metode Pemberian Tugas Berbantuan Media Gambar Dengan Teknik Mozaik Dari Bahan Alam Untuk Meningkatkan Kemampuan Motorik Halus Anak Usia Dini," Jurnal Pendidikan Anak Usia Dini Undiksha 2, no. Vol 2, No 1 (2014): (2014). 
the findings, parents will help their children with schoolwork by advising and encouraging them directly during the learning process 7 .

In addition to parental assistance during children's learning, parents can also contribute to helping the child's development process so that it is not hampered. This is done in the hope that the school and parents can collaborate while learning activities are carried out online. Parents can contribute by helping to instill children's faith and moral values through the practice of worshiping their Lord to increase children's faith ${ }^{8}$. If parents wish to help their children develop morality, they must model good behaviour for them and discourage negative behavior'.

There are a variety of activities that children and their parents can do at home to help improve religious and moral values. Parents should invite their children to participate in congregational worship practices, recite the Quran, pray before and after doing activities, learn to honor people that are older than them, speak respectfully to their parents, and do other activities that promote good behavior and etiquette. Since many children are at a young age, the development of religious and moral values is critical during a pandemic like what is happening now. Their behavior and attitudes are starting to get out of control, due to the lack of supervision by parents.

A young child, for example, is addicted to playing web games and viewing YouTube videos on mobile devices. The child got carried away and tried to try it out without ever understanding it. On video gaming and YouTube, a child is seen handing a knife to his parents. This condition is caused because parents did not accompany their children in interacting with gadgets ${ }^{10}$. This condition, if analyzed, should not be done by parents, given that toddlers are children who want to try new things and children who are curious about something new. In reality, this is the primary responsibility of parents in directing and providing effective learning guidance for their children, especially when it comes to homework assignments, in order to instill religious and moral values in their children.

The government's policy of requiring children to study at home has caused children to lose their academic concentration in school, resulting in limitations due to a lack of repeated exercise ${ }^{11}$. As a result of this learning, the children's attention can deteriorate, and the techniques used may bore them ${ }^{12}$. This situation makes facets of child growth less well-trained or inappropriate for the phases. One of the inseparable units for early childhood learning is the acquisition of aspects of religious and moral values. Many young children with disabilities and weaknesses, in particular, will be intelligent when it comes to religion and moral lessons. Parents' guidance and care, as

7 Euis Kurniati, Dina Kusumanita Nur Alfaeni, and Fitri Andriani, “Analisis Peran Orang Tua Dalam Mendampingi Anak Di Masa Pandemi Covid-19," Jurnal Obsesi : Jurnal Pendidikan Anak Usia Dini 5, no. 1 (2021): 1-19.

${ }^{8}$ KBBI, Aplikasi Kamus Besar Bahasa Indonesia Edisi V 0.3.2 Beta (32) (Badan Pengembangan dan Pembinaan Bahasa, Kementrian Pendidikan dan Kebudayaan, 2016).

${ }_{9}^{9}$ Subur, Pembelajaran Moral Berbasis Kisah (Yogyakarta: Kalimedia, 2015), 34.

10 Jerome Wirawan, “Anak Kecanduan Game Online: 'Memegang Pisau' Dan ‘Memukul Wajah Ibu', Dirawat Di Rumah Sakit Jiwa," Bbc.Com.

11 Dinita Vita Apriloka, Suyadi Suyadi, and Na'imah Na'imah, "The Use of Games Virus Hunter in Pandemic COVID-19 Against Development of Early Childhood," Indonesian Journal of Early Childhood Education Studies, 2020.

12 Alfiyanti Nurkhasyanah and Suyadi Suyadi, "Indonesian Journal of Early Childhood The Enhancing Cooperation Capabilities in Utilizing Used Cartons as Educational Game Tools," Jurnal IJECES 9, no. 2 (2020): 62-66. 
well as an atmosphere that educates and familiarizes them in a healthy religious learning environment, have enabled these children to memorize the Qur'an ${ }^{13}$. Many people have practiced introducing religious and moral education at home and school, both in the form of giving assignments by memorizing short Quranic surah/verses and memorizing everyday prayers, as seen from the reality of the environment ${ }^{14}$.

Since the research data is in the form of numbers and the analysis uses statistics, the research approach used in this study is quantitative research methodology using product-moment correlation analysis ${ }^{15}$. Correlation research is a mathematical technique used in this study to calculate two related variables to assess the degree of variable interaction with the aim of presenting a systematic picture of the current situation ${ }^{16}$. Quantitative study methods can be described as a research approach focused on the positivist theory that is then used to analyze specific populations by gathering data through a research questionnaire with the goal of testing hypotheses that have been developed ${ }^{17}$. Before conducting the research, the researcher tested the instrument by using the validity test using the product moment and tested its reliability using alpha cronbach.

The participants in this study were all teachers in early childhood education units who were assigned to 6 (six) combined teachers from two PAUD IT ADAR institutions, namely KB Abdi Desa and RA Ar-Rafif in Tirtomartani Village, Kalasan District, Sleman Regency, Yogyakarta Special Region, to work on aspects of the growth of religious and moral values in early childhood.

By looking at the observation instructions, data collection methods are used to reveal qualitative data, which is then collected with yes, no, sometimes, and never alternatives. It is then distributed to teachers in the PAUD IT ADAR institution by comparing the suitability with items or indicators that have been prepared. The essence of study data is used to begin the analysis by performing assumption tests to draw generalizations or conclusions. The assumption test is a data interpretation test that includes a normality test, a linearity test, and a hypothesis test, all of which are measured using SPSS 23 for Windows.

Based on the explanation of problems in the aspects of the development of religious and moral values in early childhood, the use of the assignment method during the Covid-19 pandemic is considered to be able to help in instilling moral religious values for children aged 2-6 years. Many previous studies have been conducted to investigate methods of inculcating religious and moral values for early childhood. However, those researches still focus on learning programs such as setting the climate of the school environment, home visit activities as an alternative in strengthening religious and moral values ${ }^{18}$. A number of researchers also studied

${ }^{13}$ Grid Network, "Kisah Naja, Hafiz Cilik Yang Mampu Hafal 30 Juz Al Quran Meski Divonis Lumpuh Otak Sejak Lahir," Tribunnews.Com.

14 Malikus Solekha, Pendidikan Agama Islam: Materi Pembelajaran Perguruan Tinggi, ed. Adiyta Ari, Pertama. (Yogyakarta: Penerbit Andi CV Andi Ofset, 2017).

15 Sugiyono, Metode Penelitian Pendidikan Pendekatan Kuantitatif, Kualitatif, Dan RED (Bandung: Alfabeta, 2013).

16 Suharsimi Arikunto, Prosedur Penelitian (Jakarta: Rineka Cipta, 2013).

17 Sugiyono, Metode Penelitian Kuantitatif Dan RED (Bandung: Alfabeta, 2011).

18 Durrotun Mumtazah and Sutama Sutama, "Program Home Visit: Penguatan Perkembangan Nilai Agama Dan Moral Anak Usia Dini Di Era New Normal," Golden Age: Jurnal Ilmiah Tumbuh Kembang Anak Usia Dini 6, no. 1 (March 31, 2021): 37-46, accessed April 15, 2021, http://ejournal.uin-suka.ac.id/tarbiyah/index.php/goldenage/article/view/3667; Amir 
teaching methods in increasing religious and moral values such as storytelling methods, demonstrations, field trips, and habituation ${ }^{19}$. In addition, previous researchers have also studied various implementations that have an impact on children's religious and moral values ${ }^{20}$. However, this research focuses on examining the effect of assignment methods on religious and moral values during the pandemic which makes this study has a different point of view from previous research. Therefore, this study is trying to provide information to teachers, parents, and the community about assignment methods that can optimize aspects of children's religious and moral values.

\section{B. The Assignment Method}

The assignment method is a learning method that is applied to children. Several theories reveal that the assignment method is one of the effective methods for teaching science to students. The way of its presentation is through giving assignments in the form of sheets of paper or oral assignments so that children do them. The assignment method is used by the teacher as material to train children's understanding of the science taught by the teacher. This method can be applied to children in groups or individually by giving assignments as a basis for children's training so that the results can be used as an evaluation of the results of children's understanding of learning ${ }^{21}$.

The advantage of this assignment is as a material to instill responsibility for students in carrying out assignments given by the teacher. If teachers often give assignments to children, then indirectly the teachers provide exercises of self-control, responsibility, and problem-solving in doing assignments based on children's understanding. The 3 phases, in this case, are; 1 ) the educator gives assignments to the children, 2) the children do exercises and work on assignments, and then 3 ) the teacher takes an evaluation of the tasks done by students. In this phase, a teacher must be clear in directing and giving good assignments for children, so that this does not burden the

Syamsudin, "Pengaruh Iklim Keagamaan Lembaga Paud Terhadap Perkembangan Nilai Agama Dan Moral Anak Usia Dini Se-Kota Yogyakarta," Jurnal Pendidikan Anak 6, no. 2 (January 2, 2018): 99-108, accessed April 15, 2021, https://journal.uny.ac.id/index.php/jpa/article/view/17698.

${ }^{19}$ Kusnilawati Kusnilawati, Mohammad Fauziddin, and Astuti Astuti, "Meningkatkan Aspek Perkembangan Nilai Agama Dan Moral Anak Usia Dini Dengan Penerapan Metode Bercerita Tema Islami," Aulad: Journal on Early Childhood 1, no. 1 (December 2, 2018): 28-38, accessed April 15, 2021, https://aulad.org/index.php/aulad/article/view/4; Novia Safitri, Cahniyo Wijaya Kuswanto, and Yosep Aspat Alamsyah, "Metode Penanaman Nilai-Nilai Agama Dan Moral Anak Usia Dini," Journal of Early Childhood Education (JECE) 1, no. 2 (December 30, 2019): 29-44, accessed April 15, 2021, http://dx.doi.org/10.15408/jece.v1i2.13312; Mutiara Sari Dewi, "Proses Pembiasaan Dan Peran Orang Terdekat Anak Sebagai Upaya Penanaman Nilai Agama Dan Moral Pada Anak Usia Dini," Seling: Jurnal Program Studi PGRA 3, no. 1 (January 6, 2017), accessed April 15, 2021, http://jurnal.stitnualhikmah.ac.id/index.php/seling/article/view/201.

${ }_{20}$ Rizki Ananda, "Implementasi Nilai-Nilai Moral Dan Agama Pada Anak Usia Dini," Jurnal Obsesi : Jurnal Pendidikan Anak Usia Dini 1, no. 1 (June 10, 2017): 19-31, accessed April 15, 2021, https://www.obsesi.or.id/index.php/obsesi/article/view/28; Rika Widya and Munisa, "Metode Penanaman Nilai Moral Dan Agama Pada Anak Usia Dini Di Paud Ummul Habibah Desa Kelambir V Kebun," Ilmiah Abdi Ilmu 12, no. 2 (2019): 58-63, accessed April 15, 2021, http://jurnal.pancabudi.ac.id/index.php/abdiilmu/article/view/715/677.

21 Siti Nur Aidah, Cara Efektif Penerapan Metode Dan Model Pembelajaran (Bantul, Yogyakarta: Penerbit KBM Indonesia, 2020). 
children in thinking about doing it because the task is very difficult and makes the child mentally burdened 22 .

Another benefit of this approach is that it will help children develop their direct and formal reasoning skills. Since the training system includes hands as part of the task, the assignment process will also help students improve their muscle control. When doing tasks, the eyes and hand muscles work together indirectly. Students' eyes are used as visual instruments to see and analyze what questions need to be answered carefully. The hand muscles' function in the assignment dilemma is to serve as a tool for the child to do things that he or she understands. All of this will teach the children how to think, how to begin new skills, and how to understand science indirectly ${ }^{23}$.

\section{The Early Childhood Development Aspects}

Early Childhood is a child who is categorized from the age of 0-6 years. Meanwhile, according to the characteristics, the child's age is categorized into three parts, namely the baby born from the age of 0-12 months, the toddler from the age of 13 years, and the preschool period from the age of 4-6 years ${ }^{24}$. During this age, the role of parents must stimulate children when they were just born until they grow up. All stimulation, direction, guidance, support, and encouragement of parents start from the baby's age, that is, from 0-6 years. The task of parents is to stimulate the level of growth and development of children, starting from stimulation of crawling, walking, eating, talking, moving, and so on. Parents must also provide good nutrition for their children, especially during infancy. This is because, at infancy, children are susceptible to disease, and parents must be extra to stimulate. As for the period of early childhood education, children are categorized as children in the golden age who are ready to receive stimulation of growth and development in order to improve the quality of children in the future ${ }^{25}$.

If we understand the features of early childhood, we will help them develop well. This is due to the fact that the thinking habits of children in their early years vary from those of older children. Self-centeredness, being special, constantly going and asking questions, dreaming, adventuring, doing new things, empathy, and imitating other people's actions are all traits of early childhood 26 . With these characteristics, parents must guide and stimulate them properly and correctly in accordance with the aspects of development and guidance of the Qur'an in the surah Luqman which explains that parents should stimulate children based on good faith, morals, and behavior for children so that they are accustomed to do good and valuable things according to religious guidance 27 . In addition to guidance, early childhood has the characteristics of like to play. When a child is playing, he or she is learning on his or

${ }^{22}$ Rita Khathir and Taufiq A. Gani, Oase Pandemi COVID-19 Based On True Stories Jilid 2, 2nd ed. (Syiah, Banda Aceh: Syiah Kuala University Press, 2020).55

23 Alfitriani Siregar, Metode Pengajaran Bahasa Inggris Anak Usia Dini (Medan: Lembaga Penelitian dan Penulisan Ilmiah Aqli, 2018). 72

24 Muhiyatul Huliyah, "Hakikat Pendidikan Anak Usia Dini," Jurnal As-Sibyan 1, no. 1 (2016): 1-19. hlm.27

${ }^{25}$ Loeziana Uce, “The Golden Age : Masa Efektif Merancang Kualitas Anak” (2015): 7792.

${ }^{26}$ Husnuzziadatul Khairi, “Kraktersitik Perkembangan Anak Usia Dini 0-6 Tahun,” Jurnal Warna 2, no. 2 (2018): 21-14.

27 Muhammad Nasir, "Internalisasi Nilai Akhlak Anak Menurut Surat Al-Luqman," Jurnal At-T'dib, Jurnal Ilmiah Pendidikan Islam 10, no. 1 (2018): 1-10. 
her own. Children can be stimulated in cognitive, language, motor, mathematical logic, religious morals, social-emotional, and artistic areas by games and play activities 28 .

Six developmental factors, including aspects of moral faith, language aspects, motor aspects, psychological and emotional aspects, cognitive aspects, and creative aspects, must be stimulated by parents. Parents will promote their children's development and growth by providing them with engaging learning media and experiences related to the six facets of child development ${ }^{29}$. Early childhood can be stimulated with a number of fascinating lessons so that children can not get bored quickly. Teachers should use the Montessori concept to stimulate children by allowing them to act and explore freely, providing organized play for learning, and providing practical activities.

\section{Religious and Moral Values}

In Islamic education, religion and morals are taught as part of the curriculum. Religious beliefs are a means of comprehending the element of religion in terms of religious creeds to still follow Allah SWT's orders to avoid all of His prohibitions ${ }^{30}$. From infancy to adulthood, parents must play an important role in instilling religious beliefs in their children. Parents must provide a religious environment in which their children can learn to pray according to their everyday routines. Moral values play an important role in instilling healthy morality and conduct in youth, as well as keep them away from poor morals. Moral behaviour is described as behavior that stems from within the children and is based on a pattern of good behavior (children themselves). It means that a person's moral character is determined by his or her personality while dealing with others ${ }^{31}$. In the realm of Islamic education application principles, religious and moral values are included. The nature of Islamic education's importance as outlined in Islamic principles and morality will assist teachers in motivating students to engage in Islamic practices that are beneficial to themselves and others $^{32}$.

In order to teach Islamic education to students, religious and moral values must be established. Early childhood moral education must be incorporated into the teaching curriculum ${ }^{33}$. The function of building good morals and behavior can reflect the religious character and good character. Religious values can develop a good religious-spiritual character and confidence in worshiping Allah SWT and staying away from all His prohibitions. Moral values can develop honest character, behave

${ }_{28}$ M. Fadlillah, Buku Ajar Bermain E Permainan Anak Usia Dini (Jakarta: Prenada Media Group, 2017).

${ }^{29}$ Herman Zaini and Kurnia Dewi, "Pentingnya Media Pembelajaran Anak Usia Dini," Jurnal Raudlatul Atfal, Jurnal Pendidikan Anak Usia Dini 1, no. 1 (2017): 1-19.

${ }^{30}$ Mufatihatut Taubah, "Pendidikan Anak Dalam Keluarga Perspektif Islam. Mufatihatut Taubah (Dosen STAIN Kudus Prodi PAI)," JUrnal Pendidikan Agama Islam 3, no. 1 (2016): 109136.

31 Habibu Rahman and Rita Kencana, Pengembangan Nilai Agama Dan Moral Bagi Anak Usia Dini (Tasik Malaya, Jawa Barat: Edu Publiser, 2020).120

32 Ade Imelda Frimayanti, “Implmentasi Pendidikan Nilai Dalam Pendidikan Agama Islam," Al-Tadzkiyyah: Jurnal Pendidikan Islam 8, no. 2 (2017): 1-21.

33 Chi Wai Chan, "Moral Education in Hong Kong Kindergartens: An Analysis of the Preschool Curriculum Guides," Global Studies of Childhood 10, no. 2 (June 1, 2020): 156-169, accessed May 5, 2021, https:/ /journals.sagepub.com/doi/10.1177/2043610619885385. 
politely, respect parents, and have sympathy and empathetic behavior for others ${ }^{34}$. The development of religious values is more like a belief in doing something similar to the individual for His Lord as they grow. Moral values development is described as an action that is considered to be positive and acknowledged by others. When children, for example, do something kind for their teachers at school, they have shown positive moral behavior ${ }^{35}$.

In the book, Tarbiyatul Aulad Fil Islam, written by Abdullah Nashih Ulwan, theological and moral principles should have been offered to students when they were in the womb. Religious and moral values are based on religious principles, religious creed, and the mother's sanctity during pregnancy at the time. Educators are obligated to make religious and moral beliefs the foundation of a child's identity to live life in the world after they are born ${ }^{36}$. Abdullah Nashih Ulwan explained that religious and moral values can make humans, especially in early childhood, live in peace and prosperity because they always involve the belief between Rabb and His creation. This can straighten deviant behavior in children. Children will always do everything through religious and moral values ${ }^{37}$.

\section{E. The Influence of Assignment Methods on the Development Aspects of Religious and Moral Values During the Covid-19 Pandemic \\ 1. Data Normality Test}

The results of the research on the data normality test show that the intended data is based on a sample originating from the population with a normal distribution. In addition, the technique used in this normality test uses the test of Kolmogorov-Smirnov. The results of the data normality test using Kolmogorov-Smirnov through SPSS 23 for windows yield a significance level of 0.94 which can be said to be significant, that is, if the significance level is more than 0.05 . Meanwhile, from the results of the normality test with Kolmogorov-Smirnov, it results in a significance level of 0.94> 0.05. Thus, it can be concluded that the data is normally distributed. Here is the table from the results of the data normality test.

Table 1. Normality Test Results

\begin{tabular}{llr}
\hline \multicolumn{3}{c}{ One-Sample Kolmogorov-Smirnov Test } \\
\hline & \multicolumn{2}{c}{$\begin{array}{c}\text { Religious and moral } \\
\text { values }\end{array}$} \\
\hline $\mathrm{N}$ & \multicolumn{6}{c}{} \\
\hline Normal Parameters ${ }^{\mathrm{a}, \mathrm{b}}$ & Mean & 23.67 \\
\cline { 2 - 3 } & Std. Deviation & 1.966 \\
\hline Most Extreme Differences & Absolute & .302 \\
\cline { 2 - 3 } & Positive & .302 \\
\cline { 2 - 3 } & Negative &. .216 \\
\hline Statistical Test & & .302 \\
\hline
\end{tabular}

34 Asti Inawati, "Strategi Pengembangan Moral Dan Nilai Agama Untuk Anak Usia Dini," Al-Athfal: Jurnal Pendidikan Anak 3, no. 1 (2017): 1-14.

35 Doni Koesoema, Pendidikan Karakter: Strategi Mendidik Anak Di Zaman Global, Kedua. (Jakarta: PT Grasindo, 2010). 202

36 Abdullah Nashih Ulwan, Kitab Tarbiyyatul Aulad Fil Islam (Mesir: PT Darussalam, 2013). 133

37 Ibid.135 


\begin{tabular}{ll}
\hline Asymp. Sig. (2-tailed) & $.094^{\mathrm{c}}$ \\
\hline a. Test distribution is Normal. & \\
\hline b. Calculated from data. & \\
\hline c. Lilliefors Significance Correction. &
\end{tabular}

\section{Linearity Test}

The significance test of the regression line coefficient and its linearity based on the results of the analysis of the independent variables and the dependent variable shows that the result of significant value is 0.753 greater than 0.05 with a frequency of 0.113 . Thus, it can be concluded that the linear regression model has a significance level of $>0,05$. This can be seen in the table below.

Table 2. Linearity Test

\begin{tabular}{|c|c|c|c|c|c|c|}
\hline \multicolumn{7}{|c|}{ ANOVAa $^{a}$} \\
\hline & Model & $\begin{array}{r}\text { Sum of } \\
\text { Squares }\end{array}$ & Df & $\begin{array}{r}\text { Mean } \\
\text { Square }\end{array}$ & $\mathrm{F}$ & Sig. \\
\hline \multirow[t]{3}{*}{$\overline{1}$} & Regression & .533 & 1 & .533 & .113 & $.753^{\mathrm{b}}$ \\
\hline & Residual & 18.800 & 4 & 4.700 & & \\
\hline & Total & 19.333 & 5 & & & \\
\hline \multicolumn{7}{|c|}{ a. Dependent Variable: Religious and Moral Values } \\
\hline \multicolumn{7}{|c|}{ b. Predictors: (Constant), Assignment } \\
\hline
\end{tabular}

\section{T-test}

In this study, the hypothesis test uses the t-test which is intended to determine how the effect of the assignment method on aspects of the development of religious and moral values in early childhood is. This t-test aims to know how much influence that one independent variable has in explaining the dependent variable. Based on the results of the study, it shows that the coefficient at this significance level is 0.753 , in which data is greater than $>0.05$. Thus, during the Covid-19 pandemic, the assignment method has a significant influence on aspects of the development of religious and moral values in early childhood.19. The assignment method indirectly accustoms children to applying and instilling religious learning in everyday life, which is why it is said to be influential. This can be seen from the data generated by teachers in PAUD IT ADAR in the following table:

Table 3. Hypothesis Test Results

\begin{tabular}{|c|c|c|c|c|c|}
\hline \multicolumn{6}{|c|}{ Coefficients ${ }^{a}$} \\
\hline & Un: & oefficients & $\begin{array}{r}\text { Standardized } \\
\text { Coefficients } \\
\end{array}$ & & \\
\hline Model & B & Std. Error & Beta & $\mathrm{t}$ & Sig. \\
\hline (Constant) & 19.000 & 13.882 & & 1.369 & .243 \\
\hline Assignment & .200 & .594 & .166 & .337 & .753 \\
\hline
\end{tabular}

a. Dependent Variable: Religious and Moral Values

Based on the results of the average data analysis in this assignment method, the resulting score was 23.67 with a standard deviation of 1.966 . Aside from seeing the changes in the resulting score based on the hypothesis test using the $t$-test, the data shows that $t$ is greater than $t$ table, so that $H_{o}$ is rejected and $H_{a}$ is accepted. Thus, the assignment method affects developing aspects of the development of religious and moral values in early childhood, especially in the era of the Covid-19 pandemic 
through distance teaching and learning activities.

Humans intrinsically as religious creatures tend to have substantial religious values and perennial moral-spiritual values ${ }^{38}$. They certainly have a life guideline for activities according to norms. The implementation of basic religious and moral values can be done from an early age. The beginning of its implementation is done through the introduction of the value of faith, commendable personality, and devotion to older people ${ }^{39}$. The real implication of the application of religious values and morality cannot be separated from the ability of each individual/child. A set of moral values can be expanded through experience and education ${ }^{40}$. As a result, education must emphasize the importance of the learning process and integrated moral knowledge at all levels ${ }^{41}$.

Islamic religious learning has an indirect effect on all approaches used, including the practice of assigning tasks to children. The child's social life is influenced in the sense that he becomes used to praying before and after performing tasks, for example. Children begin to help at home, memorize brief Quranic verses, and keep clean in this pandemic period. Over the pandemic, children learned to practice good hygiene, beginning with personal hygiene, home cleanliness, and environmental cleanliness, following government health protocol guidelines ${ }^{42}$. Therefore, building sensitivity is the main task of moral education to move one's heart and mind to act according to applicable norms ${ }^{43}$.

Moral education is able to bring changes to itself and others ${ }^{44}$. The stimulation of moral education is inseparable from indicators of imitating religious behavior (prayer, praying, greeting), carrying out a commendable attitude, mutual respect, knowing God, and recognizing interfaith worship ${ }^{45}$. Embedding the value of Islamic monotheism fosters one's faith and morality in life ${ }^{46}$. The ability of teachers to design

38 Ion Croitoru and Heliana Munteanu, "The Moral-Religious Education - A Support of Self-Conscience Training," Procedia - Social and Behavioral Sciences 116 (February 21, 2014): 21552163; Muhammad Harfin Zuhdi, "Visi Islam Rahmatan Lil 'Alamin," AKADEMIKA: Jurnal Pemikiran Islam 16, no. 2 (2011): 149-170, accessed May 5, 2021, https://ejournal.metrouniv.ac.id/index.php/akademika/article/view/173.

39 Mubasyaroh Mubasyaroh, "Model of Religious Study and Moral Values in TK Putra Harapan Nalumsari Jepara," Ta'dib 21, no. 2 (December 31, 2016): 191, accessed April 15, 2021, https://doaj.org.

40 Suatmo Pantja Putra, "A Study on Moral Values as Reflected by Two Main Characters in William Shakespeare's Macbeth," EnJourMe (English Journal of Merdeka) : Culture, Language, and Teaching of English 4, no. 1 (July 30, 2019): 4, accessed April 15, 2021, http://jurnal.unmer.ac.id/index.php/enjourme/article/view/3613.

41 Phosri Worawuth et al., "Integrated Learning Teacher Professional Development in Primary Schools," Procedia - Social and Behavioral Sciences 112 (February 7, 2014): 775-780.

42 World Health Organization, “Coronavirus Disease ( COVID-19)” (apps.who.int, 2020).

43 Molly Andrews, "Narrative and Truth in a World of Alternative Facts: The Moral Challenge for Education," Journal of Moral Education 50, no. 1 (2021): 32-38, accessed May 5, 2021, https:/ / www.tandfonline.com/doi/abs/10.1080/03057240.2020.1770707.

44 Peter Serdyukov, "Innovation in Education: What Works, What Doesn't, and What to Do about It?," Journal of Research in Innovative Teaching E Learning 10, no. 1 (April 3, 2017): 4-33.

45 Siti Nurjanah, "Perkembangan Nilai Agama Dan Moral (Sttpa Tercapai)," Paramurobi: Jurnal Pendidikan Agama Islam 1, no. 1 (June 15, 2018): 43-59, accessed April 16, 2021, https:/ / scholar.google.co.id/sch.

46 Arif Nuh, Safri Politeknik Sawunggalih, and Aji Purworejo, Menciptakan Prinsip Moral Menuju Masyarakat Madani, AKADEMIKA: Jurnal Pemikiran Islam, vol. 17, May 20, 2012, accessed May 5, 2021, http:/ / www.ijma.org.uk/features/faith, kufrand20human rights Islam.html. 
educational activities that combine religious ethical values and principles, as well as the integration of religious and moral values in one educational curriculum, influences the process of instilling religious and moral values ${ }^{47}$. Thus, it is important to achieve the religious and moral development of children in the learning period from home (distance).

Optimization of aspects of religious and moral values when studying from home during a pandemic needs to involve various parties, especially parents. Communication is key when it is difficult to stimulate student learning (via text, various messaging applications, video calls, etc. ${ }^{48}$. The role of parents is very helpful in learning completeness through giving assignments. Communication with parents is important in optimizing children's morality and religion in the aspects of behavior, language politeness, and worship. The synergy between educators and parents during the pandemic is able to optimize aspects of children's religious and moral values by assisting the assignments that have been given by educators.

The results of this study contributed to the disclosure of assignment methods during the pandemic that had an effect on the development of aspects of religious and moral values for children aged 2-6 years. This confirms the results of research descriptions and empirical evidence of early childhood education institutions on the influence of assignment methods on aspects of religious and moral values, such as research by Novia Safitri, Cahniyo Wijaya Kuswanto, and Yosep Aspat Alamsyah ${ }^{49}$. The method of assignments not only affects the moral aspects of the child's religion but also influences the child's independence and fine motor skills ${ }^{50}$. This shows that in the conditions of the Covid-19 pandemic, the implementation of learning from home does not prevent teachers from optimizing aspects of child development through assigning fun and varied children's worksheets according to early childhood stages.

\section{F. CONCLUSION}

According to the findings of the study, the assignment method has a positive impact on the growth of religious and moral values in early childhood during the Covid-19 pandemic. The normality test produces a significance level of $0.94>0.05$, while the linearity and hypothesis test or t-test produces a significance level of $0.753>$ 0.05. As a result, the assignment method's outcomes have an impact on facets of

47 Adriana Denisa Manea, "Influences of Religious Education on the Formation Moral Consciousness of Students," Procedia - Social and Behavioral Sciences 149 (September 5, 2014): 518523; Erni Munastiwi and Marfuah, "Islamic Education in Indonesia and Malaysia: Comparison of Islamic Education Learning Management Implementation," Jurnal Pendidikan Islam 8, no. 1 (2019): 1-26.

48 Shivangi Dhawan, "Online Learning: A Panacea in the Time of COVID-19 Crisis," Journal of Educational Technology Systems 49, no. 1 (September 20, 2020): 5-22, accessed November 11, 2020, http://journals.sagepub.com/doi/10.1177/0047239520934018.

49 Safitri, Kuswanto, and Alamsyah, "Metode Penanaman Nilai-Nilai Agama Dan Moral Anak Usia Dini."

50 Fitra Yunita, Peranan Metode Pemberian Tugas Terhadap Kemandirian Anak Di Kelompok A TK Widyatama Tadulako, Bungamputi, vol. 3, December 10, 2016, accessed April 16, 2021, http://jurnal.untad.ac.id/jurnal/index.php/Bungamputi/article/view/7272; Ilmi Safitri and Muraeni Mursanib, Pengaruh Metode Pemberian Tugas Terhadap Kemampuan Motorik Halus Anak Kelompok B Tk Pgri Purnama Kel. Bambalamotu Kec. Bambalamotu Kab. Pasangkayu, Bungamputi, vol. 5, September 27, 2019, accessed April 16, 2021, http://jurnal.untad.ac.id/jurnal/index.php/Bungamputi/article/view/15615. 
religious and moral values development in early childhood, especially during the Covid-19 pandemic. This research still has many shortcomings, so that further research is needed. However, this research can contribute to opening up preliminary information for further research.

\section{REFERENCES}

Aidah, Siti Nur. Cara Efektif Penerapan Metode Dan Model Pembelajaran. Bantul, Yogyakarta: Penerbit KBM Indonesia, 2020.

Ananda, Rizki. "Implementasi Nilai-Nilai Moral Dan Agama Pada Anak Usia Dini." Jurnal Obsesi: Jurnal Pendidikan Anak Usia Dini 1, no. 1 (June 10, 2017): 19-31. $\begin{array}{lll}\text { Accessed April 15, } 2021 . & .\end{array}$ https://www.obsesi.or.id/index.php/obsesi/article/view/28.

Andini Widyastuti. Seabrek Kesalahan Guru PAUD. Yogyakarta: DIVA Press, 2016.

Andrews, Molly. "Narrative and Truth in a World of Alternative Facts: The Moral Challenge for Education." Journal of Moral Education 50, no. 1 (2021): 32-38. Accessed May 5, 2021. https://www.tandfonline.com/doi/abs/10.1080/03057240.2020.1770707.

Anik Lestyaningrum. Perencanaan Pembelajaran Anak Usia Dini. Nganjuk: CV Adjie Media Nusantara, 2017.

Apriloka, Dinita Vita, Suyadi Suyadi, and Na'imah Na'imah. "The Use of Games Virus Hunter in Pandemic COVID-19 Against Development of Early Childhood." Indonesian Journal of Early Childhood Education Studies, 2020.

Arikunto, Suharsimi. Prosedur Penelitian. Jakarta: Rineka Cipta, 2013.

Cahyani and Suyadi. "Konsep Pendidikan Anak Usia Dini Menurut Ki Hadjar Dewantara." Golden Age: Jurnal Ilmiah Tumbuh Kembang Anak Usia Dini 3, no. 4 (2018): 219-230.

Chan, Chi Wai. "Moral Education in Hong Kong Kindergartens: An Analysis of the Preschool Curriculum Guides." Global Studies of Childhood 10, no. 2 (June 1, 2020): 156-169. Accessed May 2021. https://journals.sagepub.com/doi/10.1177/2043610619885385.

Croitoru, Ion, and Heliana Munteanu. "The Moral-Religious Education - A Support of Self-Conscience Training." Procedia - Social and Behavioral Sciences 116 (February 21, 2014): 2155-2163.

Dhawan, Shivangi. "Online Learning: A Panacea in the Time of COVID-19 Crisis." Journal of Educational Technology Systems 49, no. 1 (September 20, 2020): 5-22. $\begin{array}{lll}\text { Accessed } & \text { November } & 11,\end{array}$ http://journals.sagepub.com/doi/10.1177/0047239520934018.

Direktorat Pendidikan Agama Islam RI. “Bincang Mengenai Tantangan PAI Pada PAUD/TK Di Tengah Pandemi Covid-19." Pendis.Kemenag.Go.Id.

Fadlillah, M. Buku Ajar Bermain \& Permainan Anak Usia Dini. Jakarta: Prenada Media Group, 2017.

Frimayanti, Ade Imelda. "Implmentasi Pendidikan Nilai Dalam Pendidikan Agama Islam." Al-Tadzkiyyah: Jurnal Pendidikan Islam 8, no. 2 (2017): 1-21.

Huliyah, Muhiyatul. "Hakikat Pendidikan Anak Usia Dini." Jurnal As-Sibyan 1, no. 1 (2016): 1-19.

Inawati, Asti. "Strategi Pengembangan Moral Dan Nilai Agama Untuk Anak Usia Dini." Al-Athfal: Jurnal Pendidikan Anak 3, no. 1 (2017): 1-14. 
KBBI. Aplikasi Kamus Besar Bahasa Indonesia Edisi V 0.3.2 Beta (32). Badan Pengembangan dan Pembinaan Bahasa, Kementrian Pendidikan dan Kebudayaan, 2016.

Khairi, Husnuzziadatul. "Kraktersitik Perkembangan Anak Usia Dini 0-6 Tahun." Jurnal Warna 2, no. 2 (2018): 21-14.

Khathir, Rita, and Taufiq A. Gani. Oase Pandemi COVID-19 Based On True Stories Jilid 2. 2nd ed. Syiah, Banda Aceh: Syiah Kuala University Press, 2020.

Koesoema, Doni. Pendidikan Karakter: Strategi Mendidik Anak Di Zaman Global. Kedua. Jakarta: PT Grasindo, 2010.

Kurniati, Euis, Dina Kusumanita Nur Alfaeni, and Fitri Andriani. "Analisis Peran Orang Tua Dalam Mendampingi Anak Di Masa Pandemi Covid-19." Jurnal Obsesi : Jurnal Pendidikan Anak Usia Dini 5, no. 1 (2021): 1-19.

Kusnilawati, Kusnilawati, Mohammad Fauziddin, and Astuti Astuti. "Meningkatkan Aspek Perkembangan Nilai Agama Dan Moral Anak Usia Dini Dengan Penerapan Metode Bercerita Tema Islami." Aulad: Journal on Early Childhood 1, no. 1 (December 2, 2018): 28-38. Accessed April 15, 2021. https://aulad.org/index.php/aulad/article/view/4.

Manea, Adriana Denisa. "Influences of Religious Education on the Formation Moral Consciousness of Students." Procedia - Social and Behavioral Sciences 149 (September 5, 2014): 518-523.

Mubasyaroh, Mubasyaroh. "Model of Religious Study and Moral Values in TK Putra Harapan Nalumsari Jepara." Ta'dib 21, no. 2 (December 31, 2016): 191. Accessed April 15, 2021. https:/ / doaj.org.

Muhammad Harfin Zuhdi. "Visi Islam Rahmatan Lil 'Alamin." AKADEMIKA: Jurnal Pemikiran Islam 16, no. 2 (2011): 149-170. Accessed May 5, 2021. https://ejournal.metrouniv.ac.id/index.php/akademika/article/view/173.

Mumtazah, Durrotun, and Sutama Sutama. "Program Home Visit: Penguatan Perkembangan Nilai Agama Dan Moral Anak Usia Dini Di Era New Normal." Golden Age: Jurnal Ilmiah Tumbuh Kembang Anak Usia Dini 6, no. 1 (March 31, 2021): 37-46. Accessed April 15, 2021. http://ejournal.uinsuka.ac.id/tarbiyah/index.php/goldenage/article/view/3667.

Munastiwi, Erni, and Marfuah. "Islamic Education in Indonesia and Malaysia: Comparison of Islamic Education Learning Management Implementation." Jurnal Pendidikan Islam 8, no. 1 (2019): 1-26.

Nasir, Muhammad. "Internalisasi Nilai Akhlak Anak Menurut Surat Al-Luqman." Jurnal At-T'dib, Jurnal Ilmiah Pendidikan Islam 10, no. 1 (2018): 1-10.

Network, Grid. “Kisah Naja, Hafiz Cilik Yang Mampu Hafal 30 Juz Al Quran Meski Divonis Lumpuh Otak Sejak Lahir." Tribunnews.Com.

Ni Wayan Nariasih, Nyoman Wirya, Nice Maylani Asril. "Penerapan Metode Pemberian Tugas Berbantuan Media Gambar Dengan Teknik Mozaik Dari Bahan Alam Untuk Meningkatkan Kemampuan Motorik Halus Anak Usia Dini." Jurnal Pendidikan Anak Usia Dini Undiksha 2, no. Vol 2, No 1 (2014): (2014).

Nuh, Arif, Safri Politeknik Sawunggalih, and Aji Purworejo. Menciptakan Prinsip Moral Menuju Masyarakat Madani. AKADEMIKA: Jurnal Pemikiran Islam. Vol. 17, May 20, 2012. Accessed May 5, 2021. http://www.ijma.org.uk/features/faith, kufrand20human rights Islam.html.

Nurjanah, Siti. "Perkembangan Nilai Agama dan Moral (STTPA Tercapai)." PARAMUROBI: JURNAL PENDIDIKAN AGAMA ISLAM 1, no. 1 (June 15, 2018): 43-59. Accessed April 16, 2021. https://scholar.google.co.id/sch. 
Nurkhasyanah, Alfiyanti, and Suyadi Suyadi. “Indonesian Journal of Early Childhood The Enhancing Cooperation Capabilities in Utilizing Used Cartons as Educational Game Tools." Jurnal IJECES 9, no. 2 (2020): 62-66.

Nurmalitasari, Femmi. "Perkembangan Dasar Anak Usia Prasekolah." Buletin Psikologi 23, no. 2 (2015): 103-111.

Organization, World Health. "Coronavirus Disease (COVID-19)." apps.who.int, 2020.

Putra, Suatmo Pantja. "A Study on Moral Values as Reflected by Two Main Characters in William Shakespeare's Macbeth." EnJourMe (English Journal of Merdeka): Culture, Language, and Teaching of English 4, no. 1 (July 30, 2019): 4. Accessed April 15, 2021. http://jurnal.unmer.ac.id/index.php/enjourme/article/view/3613.

Rahman, Habibu, and Rita Kencana. Pengembangan Nilai Agama Dan Moral Bagi Anak Usia Dini. Tasik Malaya, Jawa Barat: Edu Publiser, 2020.

Rika Widya, and Munisa. "Metode Penanaman Nilai Moral dan Agama pada Anak Usia Dini di Paud Ummul Habibah Desa Kelambir V Kebun." Ilmiah Abdi Ilmu 12, no. 2 (2019): 58-63. Accessed April 15, 2021. http://jurnal.pancabudi.ac.id/index.php/abdiilmu/article/view/715/677.

Safitri, Ilmi, and Muraeni Mursanib. Pengaruh Metode Pemberian Tugas terhadap Kemampuan Motorik Halus Anak Kelompok B TK PGRI Purnama Kel. Bambalamotu Kec. Bambalamotu Kab. Pasangkayu. Bungamputi. Vol. 5, September 27, 2019. Accessed April 16, 2021. http://jurnal.untad.ac.id/jurnal/index.php/Bungamputi/article/view/15615.

Safitri, Novia, Cahniyo Wijaya Kuswanto, and Yosep Aspat Alamsyah. "Metode Penanaman Nilai-Nilai Agama dan Moral Anak Usia Dini." Journal of Early Childhood Education (JECE) 1, no. 2 (December 30, 2019): 29-44. Accessed April 15, 2021. http://dx.doi.org/10.15408/jece.v1i2.13312.

Sari Dewi, Mutiara. "Proses Pembiasaan dan Peran Orang Terdekat Anak sebagai Upaya Penanaman Nilai Agama dan Moral pada Anak Usia Dini." SELING: Jurnal Program Studi PGRA 3, no. 1 (January 6, 2017). Accessed April 15, 2021. http://jurnal.stitnualhikmah.ac.id/index.php/seling/article/view/201.

Satibi, Otib. Metode Pengembangan Moral Dan Nilai-Nialai Agama. Jakarta: Universitas Terbuka, 2013.

Serdyukov, Peter. "Innovation in Education: What Works, What Doesn't, and What to Do about It?" Journal of Research in Innovative Teaching $\mathcal{E}$ Learning 10, no. 1 (April 3, 2017): 4-33.

Siregar, Alfitriani. Metode Pengajaran Bahasa Inggris Anak Usia Dini. Medan: Lembaga Penelitian dan Penulisan Ilmiah Aqli, 2018.

Solekha, Malikus. Pendidikan Agama Islam: Materi Pembelajaran Perguruan Tinggi. Edited by Adiyta Ari. Pertama. Yogyakarta: Penerbit Andi CV Andi Ofset, 2017.

Subur. Pembelajaran Moral Berbasis Kisah. Yogyakarta: Kalimedia, 2015.

Sugiyono. Metode Penelitian Kuantitatif Dan RED. Bandung: Alfabeta, 2011.

- - . Metode Penelitian Pendidikan Pendekatan Kuantitatif, Kualitatif, Dan RED. Bandung: Alfabeta, 2013.

Susanto, Ahmad. Perkembangan Anak Usia Dini: Pengantar Dalam Berbagai Aspeknya. Jakarta: Kencana Prenamedia Group, 2011.

Syamsudin, Amir. "Pengaruh Iklim Keagamaan Lembaga Paud Terhadap Perkembangan Nilai Agama Dan Moral Anak Usia Dini Se-Kota Yogyakarta." Jurnal Pendidikan Anak 6, no. 2 (January 2, 2018): 99-108. Accessed April 15, 2021. https://journal.uny.ac.id/index.php/jpa/article/view/17698.

Taubah, Mufatihatut. "Pendidikan Anak Dalam Keluarga Perspektif Islam. 
Mufatihatut Taubah (Dosen STAIN Kudus Prodi PAI)." JUrnal Pendidikan Agama Islam 3, no. 1 (2016): 109-136.

Uce, Loeziana. “The Golden Age : Masa Efektif Merancang Kualitas Anak” (2015): 7792.

Ulwan, Abdullah Nashih. Kitab Tarbiyyatul Aulad Fil Islam. Mesir: PT Darussalam, 2013.

Wirawan, Jerome. “Anak Kecanduan Game Online: 'Memegang Pisau' Dan 'Memukul Wajah Ibu', Dirawat Di Rumah Sakit Jiwa." Bbc.Com.

Worawuth, Phosri, Chusorn Prayuth, Somprach Kanokorn, Kuntajai Udomporn, Arrard Chadchawarn, and Phosri Wilawan. "Integrated Learning Teacher Professional Development in Primary Schools." Procedia - Social and Behavioral Sciences 112 (February 7, 2014): 775-780.

Yunita, Fitra. Peranan Metode Pemberian Tugas Terhadap Kemandirian Anak Di Kelompok A TK Widyatama Tadulako. Bungamputi. Vol. 3, December 10, 2016. Accessed April 16 , http://jurnal.untad.ac.id/jurnal/index.php/Bungamputi/article/view/7272.

Zaini, Herman, and Kurnia Dewi. "Pentingnya Media Pembelajaran Anak Usia Dini." Jurnal Raudlatul Atfal, Jurnal Pendidikan Anak Usia Dini 1, no. 1 (2017): 1-19. 
